\title{
The relationship between the vegetarian lacto diet and depression in the Sri Sri Jagannath Gaurangga Pasraman Community
}

\section{Octhovianty Palyngan', I Wayan Westa², Anak Ayu Sri Wahyuni2, Ni Ketut Sri Diniari²}

'Department of Psychiatry, Wamena General Hospital, West Papua, Indonesia

${ }^{2}$ Department of Psychiatry, Faculty of Medicine, Udayana University, Bali, Indonesia

\section{Cite this article:}

Palyngan O, Westa IW, Wahyuni AAS, Diniari NKS. The relationship between the vegetarian lacto diet and depression in the Sri Sri Jagannath Gaurangga Pasraman Community. Journal of Clinical and Cultural Psychiatry. 202I;2(I):7-10. DOI: I0.36444/jccp.v2il.2

\section{Corresponding author:}

dr. Ni Ketut Sri Diniari, SpKJ Department of Psychiatry, Faculty of Medicine, Udayana University Jl. Kesehatan I, Denpasar 80II4 Bali, Indonesia

Email: kt.sridiniari@unud.ac.id

\begin{abstract}
Background: Depression is one of the most common mental disorders in society. The causes of multifactorial depression are factors: biology, psychology, and socio-culture. Diet is one of the socio-cultural stressors that is thought to cause depression. Vegetarian is one type of diet that reduces animal ingredients and prefers vegetable ingredients. A vegetarian diet is thought to prevent depression. This study aims to determine the relationship of the vegetarian lacto diet with depression in the Sri Sri Jagannath Gaurangga community in Denpasar.

Material and Methods: Study participants numbered 59 people in the Sri Sri Jagannath Gaurangga Pasraman community, Denpasar City, aged 18 years or older. Research using cross sectional analytic methods. Measurement of the vegetarian lacto diet using the Indonesian version of the Mediterranean Diet Score (MedDit Score) questionnaire and depression using the Beck Depression Inventory (BDI) questionnaire. Data were analyzed descriptively and using chi square test with significance level of $<0.05$.

Results: The results showed an adequate vegetarian diet that was not depressed by $80 \%$ while a good vegetarian lacto diet that was not depressed by $78.8 \%$. There was a negative significant relationship between the vegetarian lacto diet and depression in the Sri Sri Jagannath Gaurangga community of Denpasar ( $\mathrm{p}=0.043$ ).

Conclusion: The prevalence of depression in the Sri Sri Jagannath Gaurangga Pasraman community in Denpasar was $20.3 \%$. We found that there was a significant negative relationship between the vegetarian lacto diet with depression.
\end{abstract}

Keywords: chi-square distribution, depression, Indonesia, mental disorders

\section{Introduction}

Diet is the way of person regulates the intake of food he consumes as a reaction to physiological, psychological, cultural, social, and spiritual influences. Diet is a repetitive activity that has three important components, namely type, frequency and amount. Diet is influenced by several factors such as: economic, social, cultural, religious, educational, and environmental. A healthy diet is widely used as a behavioral psychotherapy to prevent and cure disease, but an unhealthy diet will cause or aggravate a disease. ${ }^{1-3}$ Changes in diet came to the attention of researchers especially in the field of mental health. Dietary changes are one of the factors causing the incidence of depression to increase in the world today. ${ }^{4}$

Depression disorder is a fundamental disorder characterized by changes in mood or affect toward depression that occurs in all age groups. Depression is one of the most common mental disorders and affects people throughout the world. In 2011 there were 24 million people around the world experiencing dietary disorders, more women. This disorder increases the incidence of depression that is comorbid with obesity. WHO reports that $10 \%$ of adolescents and $15 \%$ to $25 \%$ of adults currently face depression and dietary disorders.56 One in five people will experience depression along the point of their lives.6 This study aims to determine the relationship and prevalence of the vegetarian lacto diet with depression in the Sri Sri Jagannath Gaurangga Pasraman (SJGP) community. 


\section{Material and Methods}

This study is a correlational analytic study with a cross sectional study conducted at the Lacto vegetarian community of Pasraman Sri Sri Jagannath Gaurangga Denpasar City in AprilJune 2019. Data sources were collected directly from research subjects by questionnaires. The inclusion criteria were the lacto vegetarian community in SJGP aged $>18$ years and willing to participate in the research by signing an informed consent. Exclusion criteria were respondents with a history of mental illness and chronic physical pain.

Subjects were selected cluster random sampling, which is a way of sampling in groups or specific areas. Samples will be taken from the vegetarian lacto community in SGJP who met the inclusion criteria and agrees with informed written consent. In this study the status of depression is the status of a depressed community that is divided into two categories, namely depression is a community status that satisfies symptoms of depression and non-depression is a community status that does not meet the symptoms of depression. The Back Depression Inventory (BDI) questionnaire was used to assess depression. The BDI instrument had been tested for validity in Indonesia. This instrument has been widely used in general by researchers in Indonesia before and has become a standardized test that has been tested and accepted both internationally and in Indonesia with good validity and reliability tests (Alpha Cronbach's value of 0.889 ).

The vegetarian lacto diet variable is defined as a vegetarian community that consumes vegetable and milk ingredients and their derivatives and does not consume garlic and onions. This instrument was measured using the Mediterranean Diet Score (MedDit Score) questionnaire, which is one of the instruments to measure a high plant-based diet score. The MedDit Score instrument is widely used as a measurement tool for research worldwide. The Indonesian version of MedDit Score has been adjusted according to the type, frequency and amount of food consumed by the Indonesian people according to the provisions of the Indonesian Dietetic Association.

The data obtained were analyzed with the help of a computer using Statistical Package for the Social Sciences (SPSS) 21st edition and displayed in tabular and narrative form. A p value of $<0.05$ was considered significant.

\section{Results}

Among 65 subjects, 6 did not return the questionnaire so that those who met the inclusion criteria and filled out the questionnaire completely totaled 59 subjects. The mean age was $38.8 \pm 1.71$ years (Table 1 ). Of the total 59 participants, $62.7 \%$ were women and $37.3 \%$ were men. Based on Table 2, the description of the research data shows that overall respondents who are on the Lacto vegetarian diet: $67.8 \%$ are sufficient and $32.2 \%$ are good. Subjects who did not show depression were 47 $(79.7 \%)$.
Table 1. Subject Characteristics

\begin{tabular}{lcc}
\hline Characteristics & N=59 & \% \\
\hline Age (years), mean \pm SD & \multicolumn{2}{c}{$38.8 \pm 1.71$} \\
\hline Gender & \multicolumn{2}{c}{} \\
$\quad$ Male & 22 & 37.3 \\
Female & 37 & 62.7 \\
\hline Body Mass Index & & 3.4 \\
Low $(<18.5 \mathrm{~kg} / \mathrm{m} 2)$ & 2 & 59.3 \\
Ideal $(18.5-24.9 \mathrm{~kg} / \mathrm{m} 2)$ & 35 & 32.2 \\
Overweight $(25-29.9 \mathrm{~kg} / \mathrm{m} 2)$ & 19 & 5.1 \\
Obese $(30.0-39.9 \mathrm{~kg} / \mathrm{m} 2)$ & 3 & \\
\hline Vegetarian for & & 13.6 \\
$\quad<5$ years & 8 & 86.4 \\
$\geq 5$ years & 51 & \\
\hline Alcohol consumption & & \\
$\quad$ Yes & 1 & 98.3 \\
$\quad$ No & 58 & \\
\end{tabular}

Table 2. Table of variable frequency distribution

\begin{tabular}{lcc}
\hline Variables & $\mathbf{N}$ & $\mathbf{\%}$ \\
\hline Diet Score & & \\
Less & 0 & 0 \\
Enough & 40 & 67.8 \\
Good & 19 & 32.2 \\
Very & 0 & 0 \\
good & & \\
\hline Depression & & \\
Yes & 47 & 79.7 \\
No & 12 & 20.3 \\
\hline
\end{tabular}

Table 3. Characteristics based on depression status

\begin{tabular}{|c|c|c|c|c|}
\hline \multirow[t]{3}{*}{ Characteristics } & \multicolumn{4}{|c|}{ Depression Status } \\
\hline & \multicolumn{2}{|c|}{ Depression } & \multicolumn{2}{|c|}{ No Depression } \\
\hline & $\mathrm{N}$ & $\%$ & $\mathrm{~N}$ & $\%$ \\
\hline \multicolumn{5}{|l|}{ Gender } \\
\hline Male & 3 & 13.6 & 19 & 86.4 \\
\hline Girl & 9 & 24.3 & 28 & 75.7 \\
\hline \multicolumn{5}{|l|}{ Body mass index } \\
\hline Less $(<18.4$ kg/m2) & 0 & 0 & 1 & 100 \\
\hline Ideal $(18.5-24.9 \mathrm{~kg} / \mathrm{m} 2)$ & 9 & 25 & 27 & 75 \\
\hline Overweight $\quad(25-29.9$ & 2 & 10.5 & 17 & 89.4 \\
\hline \multicolumn{5}{|l|}{$\mathrm{kg} / \mathrm{m} 2)$} \\
\hline Obese $(30-39.9 \mathrm{~kg} / \mathrm{m} 2)$ & 1 & 33.3 & 2 & 66.7 \\
\hline \multicolumn{5}{|l|}{ Vegetarian for } \\
\hline$<5$ years & 4 & 50 & 4 & 50 \\
\hline$\geq 5$ years & 8 & 15.69 & 43 & 84.31 \\
\hline \multicolumn{5}{|l|}{ Alcohol consumption } \\
\hline Yes & 1 & 100 & 0 & 0 \\
\hline No & 11 & 18.9 & 47 & 81.1 \\
\hline
\end{tabular}

The research data (Table 3 ) found that the most depressed were women by $24.3 \%$, while men who were not depressed were $86.4 \%$. From the body mass index (BMI), the research subjects who were most depressed were those who were obese / obese $33.3 \%$, who did not experience the greatest depression on body weight less than $100 \%$. The study subjects who drank the most alcohol experienced $100 \%$ depression, while the subjects who did not drink alcohol who did not experience depression were $81.1 \%$. Table 4 shows the $2 \times 2$ relationship between vegetarian lacto diet and depression, where the ChiSquare test obtained $\mathrm{p}=0.043$. 
Table 4. The relationship between the vegetarian lacto diet and depression

\begin{tabular}{lccccc}
\hline & \multicolumn{4}{c}{ Depression } & \multirow{2}{*}{ p } \\
\cline { 2 - 4 } Diet & \multicolumn{2}{c}{ Depression } & \multicolumn{2}{c}{ Not Depression } & \\
\cline { 2 - 5 } & $\mathrm{n}$ & $\%$ & $\mathrm{n}$ & $\%$ & \\
\hline Sufficient & 8 & 20 & 32 & 80 & \multirow{2}{*}{0.043} \\
Good & 4 & 21.1 & 15 & 78.8 & \\
\hline
\end{tabular}

\section{Discussion}

Vegetarian is a diet where there is no consumption of meat in the daily diet, which will eliminate the essential ingredients that may be needed for the synthesis of neurotransmitters.6,7 Vegetarian lacto dietary groups in addition to eating dishes made from vegetable ingredients, also consume milk and its processed products, such as cheese, butter, kefir cream, and yogurt. This group does not eat and drink from animal sources, do not eat onions and garlic.

The time or length of a vegetarian diet is one of the important sample characteristics in this study. This characteristic is important because according to previous studies, people who have been on a vegetarian diet for more than five years show low symptoms of depression. Most of the subjects who experienced depression in this study were those who had a vegetarian diet for less than 5 years which is $50 \%$. This is consistent with previous research so it will not be a refractor in the study.

Previous research has said that excessive drinking of alcohol will make people easily depressed. In this study almost all participants did not drink alcohol as many as 58 people. Research subjects who drank depression with alcohol by $100 \%$, this is in accordance with previous theories so that it will not be a biased factor in this study.

This research revealed that there is a significant relationship between the vegetarian lacto diet and depression. The SGJP community, who are on a vegetarian lacto diet, is likely to experience vitamin B12 deficiency which is mostly obtained from meat and lack of omega- 3 fatty acids found in fish, especially sea fish. Both of these substances protect us from depression. People who go on a vegetarian diet are usually these substances will be obtained from vegetables, fruit, nuts, and seeds.

However, the SGJP community carried out a vegetarian lacto diet which means they still drink milk. Milk contains vitamin B12 which is good for preventing depression. The results of this study are supported by previous studies. Several other studies explain that a vegetarian diet has a protective effect on depression. One study explained that people on a vegetarian diet have EPA levels of $0.005 \mathrm{~g}$, lower than 0.093 g omnivores ( $p<0.001$ ), DHA (0.015 vs. $0.162 \mathrm{~g}, \mathrm{p}$ $<0.01)$. This explains that the vegetarian community is easily depressed due to low levels of EPA and DHA that are not obtained from animal products.
Another study supporting this study is a meta-analysis study who found the protective effect of vegetarian diets on depression. The incidence of depression was found to be lower in the vegetarian group with an odd ratio of 0.64 ( $\mathrm{p}<0.001)$.

A report showed the vegetarian lacto diet has a protective effect on the onset of depression especially in women $(\mathrm{OR}=0.65,95 \% \mathrm{CI}=0.46-0.91) .26$ Another study reported that populations who consume vegetables more than three times per week are associated with a reduction in depressive events $(\mathrm{p}=0.039)$. A recent study showed that eating a diet high in fruits, soybeans, green tea, and vegetables can also reduce the incidence of depression.

\section{Conclusion}

The prevalence of depression in the Sri Sri Jagannath Gaurangga Pasraman community in Denpasar was 20.3\%. We found that there was a significant negative relationship between the vegetarian lacto diet with depression, which indicated the vegetarian lacto diet is associated with a decreased incidence of depression.

\section{Acknowledgment}

The authors report no conflict of interests.

\section{References}

1. Saeed A, Humayun A, Raana T, Saeed AM. Depression the Hidden Iceberg: Role of Nutrition \& Dietary Intake. IOSR Journal of Nursing and Health Science. 2015;4(5): 26-29.

2. Rechenberg K. Nutritional Interventions in Clinical Depression. Clinical Psychological Science. 2016;4(1):144-162.

3. Villegas AS, Verberne L, Irala JD, Canela MR, Toledo E, Majem LS, et al. Dietary Fat Intake and the Risk of Depression: The SUN Project. PLoS ONE. 2011;6(1):1-7.

4. Gougeon L, Payette H, Morais J, Gaudreau P, Shatenstein B, Donald KG, Dietary Patterns and Incidence ofDepression in a Cohort of Community-Dwelling Older Canadians. Journal Nutrission Health Aging. 2015;19(4): 431-432.

5. Lai SJ, Hiles S, Bisquera A, Hure JA, McEvoy M, Attia J. A systematic review and meta-analysis of dietary patterns and depression in community-dwelling adults. The American Journal of Clinical Nutrition. 2014;99(1):97-181.

6. Hergaty P. Marine Omega-3 Fatty Acids and Mood Disorders Linking The Sea and The Soul. Acta Psychiatri Scand. 2011;124:42-51. 
12. Beezhold L, Johnston C, Daigle D. Vegetarian Diets are Associated with Healthy Mood States: a Crossectional Study in Seventh Day Adventist Result. Nutritional Journal. 2010;26(9):1-10.

13. van Hees NJ, de Does WV, Giltay EJ. Coeliac disease, diet adherence and depressive symptoms. Journal of Psychosomatic Research. 2013;74(5):155-160.

14. Kaner G, Soylu M, Yüksel N, Inanç N, Ongan D. Evaluation of Nutritional Status of Patients with Depression. BioMed Research International. 2015;1(1):18-30.

15. O'Malley R. Depression Puts Low-Income Population at Even Greater Risk for Obesity and Poor Nutrition. Journal of the Academy of Nutrition and Dietetics. 2015;17(3):3743.

16. Roca M, Kohls E, Gili M, Watkins E, Owens M, Hegerl U. Prevention of depression through nutritional strategies in high-risk persons:rationale and design of the MooDFOOD prevention trial. BMC Psychiatry. 2016;16(2)24-31.
7. Saleem M, Sattar S, Zafar M, Ismail RB. Link between Eating Disorders and Depression. Pakistan Journal of Commerce and Social Sciences. 2014;8(3):925-937.

8. Molendjik M, Molero P, Pedreno S. Diet Quality and Depression Risk: A Systematic Review and Dose-Response Metaanalysis of Prospective Studies. Journal of Affective Disorder. 2018;13(1):346-354.

9. Hossein M, Vafa M, Esail A. Epirically Delivered Dietary Patterns in Relation to Psychological Disorders. Public Health Nutrition. 2015;19(2):214-217.

10. Tsai A, Chang T, Chi S. Frequent Consumption of Vegetables Predictas Lower Risk of Depression in Older Taiwanese: Result of a Prospective Population Based Study. Public Health Nutrition. 2011;15(6):1087-1092.

11. Lang U, Begliner C, Schweinfurth N. Nutritional Aspects of Depression. Cell Physiologi Biochem. 2015;37(5):10291043. 